\title{
The Development Status and Path Analysis of the New Agricultural Social Service Organization in China
}

\author{
Lei li \\ Jilin agricultural university, college of humanities, Changchun130118, China \\ lilei@jlau.edu.cn
}

Key words: new agriculture; social service organization; development status

\begin{abstract}
At present, the development of new agricultural social service organizations in China can not only promote the comprehensive agricultural production capacity and improve the income level of farmers, but also facilitate the agricultural production and rural economic and social development. Based on this, this paper analyses the current development situation and path of new agricultural social service organizations in china. First of all, this paper introduces the development status of agricultural social service organizations, mainly on the analysis of the concept, development necessity, and current situation of development. Then, based on the current situation of its development, it explores the problems existing in the development and factors restricting its development in new agricultural social service organizations in China. Finally, according to the problems existing in the development and the restricting factors, this paper puts forward suggestions to promote the development of the new agricultural social service organizations in our country: 1) to improve the institutional mechanisms of government agricultural services; 2) to key support farmer professional cooperative organization; 3) to take safeguard of the interests of farmers as the core of development and to improve the quality of service; 4) to build a modern agricultural leading enterprises; 5) to perfect the civil service organizations; 6) to improve the financial services of rural credit cooperatives.
\end{abstract}

\section{Introduction}

With the continuous progress of agriculture and rural economy, the agricultural productivity level is being constantly improved. Agricultural socialization and specialization gradually strengthen, many links in production and labor are separated and independent, and form a new organization, industry or sector. These new organizations, industries or sectors include various material supply, production services, technical services, financial services, insurance services and transport, processing, storage, marketing and other aspects of agricultural products. And as the agricultural social service is gradually improved, new agricultural social service organizations continue to emerge, all kinds of market-oriented social service organizations are continuously innovating (Choi, et al., 2015). The development of these social service organizations promotes the improvement of the comprehensive agricultural production capacity, facilitates the improvement of farmers' income level, and plays an essential role in the agricultural production and rural economic and social development.

\section{Research Content and Method}

\subsection{Development Status of New Agricultural Social Service Organizations}

\subsubsection{Concept of Agricultural Social Service Organization}

The party's Tthird Plenary Session of the 17th CPC Central Committee "Decision" pointed out: "to accelerate the construction of new agricultural social service system that takes public service institutions as the basis, organization for economic cooperation as the foundation, the leading enterprises as the backbone and other social forces as a supplement, public service and business services combined, and the special services and service coordinated."

After 30 years of reform and opening up, the level of agricultural productivity in China has been greatly improved. But facing more complicated domestic and international economic situation, China's agricultural development still exist many drawbacks. Farmers scale is small and scattered, so 
it is difficult to resist natural risk and market risk. Lots of the service system cannot get up to a higher level that farmers cannot complete the connection with the market by their own efforts. Facing the new development situation, considering the long-term development of modern agriculture in our country, there must be a new agricultural social service system to support it. Specifically speaking, we can understand the connotation of "new" from the following aspects: the new concept of service. Adhere to the "overall" service concept, and effectively establish the "three rural" service concept; new service content. Strengthen the original supporting services, while develop new ancillary services, so as to achieve a full range of services; new forms of service. The public welfare service and the management service are combined, and the special service and the comprehensive service are coordinated; new service subject. Strengthen the basic role of the cooperative economic organizations, and vigorously develop leading enterprises; new service mechanism. Establish and improve communication mechanism, incentive mechanism, problem solving mechanism between the service sector, so as to promote the formation of the resultant force mechanism.

The so-called new agricultural social service organizations, refer to new groups (including all types of professional associations, rural brokers, etc.) formed according to new principles and regulations in the socialization of agriculture production process, for people (farmers) to achieve specific goals. It is different from the previous rural organizations, which is the basic organization of agricultural socialization and modernization. It plays a very important role in the daily life of farmers (Cohen, 2016). They directly create economic benefits, and at the same time, they also indirectly provide certain practical technology promotion and information service for farmers, which has become a useful supplement to the agricultural social service system, promoting and facilitating the development of agricultural industrialization.

\subsubsection{Analysis on the Necessity of Development of Agricultural Social Service Organizations}

The importance of developing a new type of agricultural social service organization is embodied in 4 aspects, specifically introducing as follows:

1) The inevitable requirement of the development of agricultural modernization

The essence of agricultural modernization is the modernization of farmers, and the establishment and development of new agricultural social organizations provide a practical platform for the growth of new farmers.

The realization of agricultural modernization requires that the whole agriculture must have a reasonable layout, and gradually realize the regional and specialized production, and constantly improve the social level of agricultural production. In this layout, improvement and realization process, the role of the person is the key. In the final analysis, the modernization of agriculture is the modernization of the people and the modernization of the peasants (Deng, et al., 2013). From the process of agricultural modernization in some developed countries in the world, with the development of agricultural production and the improvement of the market, the degree of organization of agricultural production has been increasing.

As a result, the development of new agricultural social service organizations makes it inevitable trend of the development of agricultural modernization.

2) Conductive to improve the rural governance mechanism

At present, to avoid a variety of construction problems in rural governance mechanism, the local government choose to construct rural peasant organization system that takes peasant autonomous body and farmer organizations as the basic framework. And agricultural social service organizations can fully reflect the interests of farmers, and effectively solve the problem of the presence of flexibility of government and market in the process of rural governance. Therefore, it can improve rural governance mechanism to a certain extent, which has become an important measure to improve the rural governance mechanism.

3) Beneficial to improve the international competitiveness of China's agriculture

As the economic globalization is continuously accelerating, the internationalization of the agricultural market has become an inevitable trend. And the agricultural social service organizations are the support of China's agricultural internationalization, which has become a realistic path to 
resist risks for agricultural development. For this, the development of the agricultural social service organization is the inevitable strategy for China to improve the international competitiveness of agriculture (Farrington and Lewis, 2014). To this end, it is supposed to integrate small-scale farmers, form integrated scale economies, with the identity of the members of cooperate community, overally enter socialized market. At the same time, cultivate a batch of strong agricultural company, and further develop enterprise organization, industry associations, so as to enhance the international competitiveness of China's agriculture.

4) Organization safeguard for protecting the rights and interests of farmers

At present, China's market economy has gradually developed and the social structure has profoundly changed. The problem of farmers' rights and interests have become more and more prominent, and events that violates the interests of farmers, and the rights of farmers have occurred. There are many reasons for this phenomenon and problems, and among them, that the low organization degree of farmers, agricultural social service organization is not perfect is a more important factor. The starting point and the end result of the establishment, development and improvement of agricultural social service organizations is to safeguard the interests of farmers (Holzworth, et al., 2014). Agricultural social service organizations build an indispensable communication channels between the government and farmers. And at the same time, it eases the function alienation, organizational slack problems existing in the practice of the Villagers' Committee to a certain degree. To solve the problem of farmers' rights protection in the macro and micro two aspects, we need to pay attention to and develop agricultural social service organizations from two dimensions of the state and rural areas. Some scholars have pointed out that, in our country, workers have the "China Federation of Trade Unions", lawyers have the "National Lawyers Association", consumers have "Chinese Consumers Association", the disabled people have "China Federation of the Disabled" and so on. However, so far, there is no representative massive organization to safeguard the interests of farmers. As a result, farmers need their own organization "the Chinese National Federation Associations" (Ivanova, 2012). To this end, we should speed up the construction of agricultural social service organizations so that all types of agricultural social service organizations can make due contributions to the protection of the rights of farmers.

5) Provide strong support for the sustainable development of agriculture. In accordance with the requirements of scientific outlook on development, the direction of China's agricultural development is bound to be sustainable and modern agriculture. At present, China's agriculture and rural areas to achieve sustainable development is still facing a series of contradictions and problems. Among them, the per capita share of agricultural resources has been a prominent issue in the development of agriculture in China.

In recent years, the contradiction between economic and ecological environment is becoming more and more obvious in the agricultural production. In addition, there are food problems, rural ecological environment problems and so on. We are supposed to be based on the national conditions to explore the road of agricultural development in China, to discuss the feasible path of sustainable development of agriculture. Sustainable agriculture cannot be achieved without the participation of farmers (Kerr, 2012). The development of agricultural social service organization is the practice carrier of realizing the sustainable development of agriculture, and it is the organization innovation of solving the problem of agricultural development. Broadly speaking, the strategy of sustainable development is to promote the harmony between human beings and the nature. The sustainable development of agricultural production and life is to promote the harmony between the farmers and their agricultural production and living environment. In the organization of agricultural socialization, the majority of farmers should continuously improve the ecological consciousness and sustainable development awareness.

\subsubsection{Development Status of New Agricultural Social Service Organizations}

Agricultural socialization does not appear from ancient times, but after a long period of development and evolution process, with obvious characteristics of the times. China's agricultural socialization mainly experienced the development process from "passive to forced to active". The first stage is after the Opium War, socialized mass production seriously impact the way of agricultural 
production and management of traditional self-sufficiency type, making the historical process of China's agriculture change (Niewolny, et al., 2012); the second stage is after the establishment of the New China, with the implementation of cooperative movement and people's commune movement, national and collective powers are forced into the social service process so that the farmers lost operational autonomy, which harmed the economic benefits of farmers; the third stage is at the end of 1990s, China began to carry out market-oriented reform of the government public service agencies, and there appears "net-broken, lines-broken, and people scattered" situation, thus public service is seriously lacked; until entering the new century, China's agricultural cooperatives enter the active development stage, and gradually obtained attention and support of the country (Peterman, et al., 2014). With the change of history and space, the form of agricultural production in China has experienced the development process of agricultural industrialization, agricultural business-orientation, agricultural product-orientation, and agricultural socialization. It is worth to note that the four processes are not mutually replacement development, but mutual contact and promote each other in the process of evolution.

At present, China's agricultural social service organizations include agricultural technology extension service agencies of government and various business service organizations these two categories (Zhi and Zhuang, 2015). These agricultural social service organizations play an important role in the construction of new countryside, realization of agricultural modernization and so on. Its specific development status is shown in Table 1. 
Table 1. Development of new agricultural social service organizations

\begin{tabular}{|c|c|}
\hline Organizations & Development status \\
\hline $\begin{array}{lr}\text { Agricultural } & \text { technology } \\
\text { extension } & \text { service } \\
\text { agencies of government }\end{array}$ & $\begin{array}{l}\text { 1) The Agricultural Technology Extension Service Center } \\
\text { (station) was established from the central to the township } \\
\text { level; } \\
\text { 2) Service organization is relatively sound and service is } \\
\text { standardized; 3) Play a leading role in agricultural } \\
\text { production. } \\
\text { 4) Two kinds of service modes are carried out: the } \\
\text { administrative extension service under the government } \\
\text { leading and the self-promotion service based on the } \\
\text { fulfillment of the duty and the content of the farmers' } \\
\text { demand. } \\
\text { 5) Construct modern agricultural service information } \\
\text { platform and implement the responsibility system of } \\
\text { agricultural extension. }\end{array}$ \\
\hline $\begin{array}{lr}\text { Others } & \text { agricultural } \\
\text { social } & \text { service } \\
\text { organization } & \end{array}$ & $\begin{array}{l}\text { 1) The farmer specialized cooperative organization } \\
\text { provides agricultural services before production, production } \\
\text { technical service in production, and sales service after } \\
\text { production. In the past two years, it increases with the } \\
\text { annual rate of } 20 \% \text { to } 30 \% \text {. } \\
\text { 2) Provide professional services for farmers. By the end of } \\
\text { 2012, professional service organizations against crop pests } \\
\text { registered were more than } 25 \text { thousand, employing nearly } 1 \\
\text { million people. In 2015, the area for the implementation of } \\
\text { Commission ruled against crop pests reached } 440 \text { million } \\
\text { acres, covering } 15 \% \text { of major grain crops. } \\
\text { 3) Agricultural industrialization leading enterprises can } \\
\text { directly or through cooperatives (government or Village } \\
\text { Commitee) indirectly provide the means of production, } \\
\text { capital and technology base for the farmers, and the acquire } \\
\text { products according to the contract. By the end of } 2015 \text {, all } \\
\text { kinds of country's agricultural industrialization organization } \\
\text { were more than } 280 \text { thousand, driving } 110 \text { million } \\
\text { households, and each home annual increasing income more } \\
\text { than } 2400 \text { yuan. } \\
\text { 4) A variety of other social organizations play a role in the } \\
\text { agricultural social services. Folk Village Science and } \\
\text { Technology Service Station provide technical advice, } \\
\text { agricultural supply and market information services for } \\
\text { farmers; Scientific Research Institutes provide new means } \\
\text { of production and processing technology for farmers; } \\
\text { farmer brokers provide a large number of effective services } \\
\text { in the agricultural products market development and } \\
\text { product sales; Rural Credit Cooperatives give financial } \\
\text { support and preferential lending rates for farmers to buy } \\
\text { agricultural loans, developing characteristic agriculture and }\end{array}$ \\
\hline
\end{tabular}


so on.

\subsection{Problems in the Development of New Agricultural Social Service Organizations}

At present, there are still some problems in the new agricultural social service organization development, mainly reflected in the following 5 aspects: 1) the system and mechanism of government agricultural services to some extent cannot adapt to the needs of agricultural development; 2) the decision and operation mechanism of farmer professional cooperative organizations initialized late, low in volume and level, and the quality of comprehensive membership is not high, the degree of organization is low (Rizzo, et al., 2013); 3) agricultural professional services was in the early stage of development, unbalanced in development, small in number, small in scale, insufficient in capital investment, not enough market training force, technical training and guidance unable to meet the needs, and also lack of risk protection system; 4) agricultural industrialization leading enterprises were small in scale, single in structure of products, and not strong in service consciousness (Ugwuoke and Onah, 2015); 5) civil service subjects under a lot of risks (technology, information and capital), so it is difficult to guarantee the quality of service.

\subsection{Factors Restricting the Development of New Agricultural Social Service Organizations}

The development of new agricultural social service organization is affected and restricted by many factors, including internal factors and external factors. Among them, the insufficient national investment resources of agriculture are one of the main factors restricting its development. In a certain period of time, the economic and social development of our country is based on the cost of sacrificing the interests of agriculture and farmers. It to a large extent weakens the actual service ability of the agricultural social service departments and organizations; furthermore, the unbalanced development of the village collective economic service organizations also restricts new agricultural social service organization development to a certain extent; in addition, the conservative and low ideology and cultural level, and low autonomy in the market competition has a certain influence in new agricultural social service organization development.

\section{Research Results and Discussion}

Based on the above research, aiming at the existing problems and constraint factors in the development of new agricultural social service organizations (Stamoulis and Hemrich, 2016), this paper explores the development path of new agricultural social service organizations, and puts forward the suggestions for the development, specific recommendations as shown in Table 2. 
Table 2. Suggestions for new agricultural social service organizations development

\begin{tabular}{|c|c|}
\hline Suggestions & Specific measurements \\
\hline $\begin{array}{l}\text { Improve the institutional } \\
\text { mechanisms of Government } \\
\text { Agricultural } \\
\text { Institutions }\end{array}$ & $\begin{array}{l}\text { 1) Establish the public welfare function of the county and } \\
\text { township two level agricultural service organizations, and } \\
\text { strengthen the agricultural science and technology extension } \\
\text { service. } \\
\text { 2) Implement organization mechanism establishment, } \\
\text { personnel allocation, technical equipment and financial } \\
\text { support. } \\
\text { 3) Facilitate the service mechanism innovation and promote } \\
\text { mature service model. } \\
\text { 4) Improve and strengthen the functions of public service. }\end{array}$ \\
\hline $\begin{array}{lr}\begin{array}{l}\text { Focus on } \\
\text { farmers' }\end{array} & \text { supporting } \\
\text { Cooperative Organizations }\end{array}$ & $\begin{array}{l}\text { 1) Take the improvement of the professional cooperative } \\
\text { organization service level of farmers as the focus. } \\
\text { 2) Suggest that the government should set up special funds } \\
\text { to support the specialized cooperative economic organization } \\
\text { of farmers. } \\
\text { 3) Improve the management of the internal structure and } \\
\text { operation mechanism of the organization. } \\
\text { 4) Regulate the system of interest distribution. }\end{array}$ \\
\hline $\begin{array}{l}\text { Improve service quality by } \\
\text { taking safeguard of the } \\
\text { interests of farmers as the } \\
\text { core of development }\end{array}$ & $\begin{array}{l}\text { 1) The new agricultural social service organizations should } \\
\text { take the maintenance of the interests of farmers as the } \\
\text { starting point and the end result of all services and activities, } \\
\text { pay attention to the development of modern agricultural } \\
\text { information services, and improve service quality. } \\
\text { 2) Promote the development of agricultural trade } \\
\text { associations, and take farmers income, corporate profits as } \\
\text { the development goals. } \\
\text { 3) All kinds of agricultural social service organizations } \\
\text { should establish service awareness. }\end{array}$ \\
\hline $\begin{array}{l}\text { Create a modern agricultural } \\
\text { leading enterprise }\end{array}$ & $\begin{array}{l}\text { 1) Establish the awareness of agricultural leading } \\
\text { enterprises brand. } \\
\text { 2) Improve the agricultural leading enterprise staff quality } \\
\text { and enhance their service capacity. } \\
\text { 3) Speed up the improvement of link mechanism of the } \\
\text { interests of enterprises and farmers } \\
\text { 4) Play the leading role of leading enterprises in agriculture. }\end{array}$ \\
\hline $\begin{array}{l}\text { Improve civil } \\
\text { organizations }\end{array}$ & $\begin{array}{l}\text { 1) Increase policy support, develop rural brokers team, and } \\
\text { create an open and fair competitive environment for the } \\
\text { legitimate business operators and civilized business. } \\
\text { 2) Improve the organization level of rural brokers, and } \\
\text { guide the rural brokers to establish associations and industry } \\
\text { associations; strengthen the training of rural brokers to } \\
\text { improve their comprehensive quality. } \\
\text { 3) Strengthen the construction of agricultural products } \\
\text { wholesale market and construct the effective circulation }\end{array}$ \\
\hline
\end{tabular}




\begin{tabular}{|l|l|}
\hline $\begin{array}{l}\text { Improve the rural credit } \\
\text { cooperatives financial } \\
\text { services }\end{array}$ & $\begin{array}{l}\text { 1) Increase agricultural credit, and priority to meet the credit } \\
\text { needs of farmers. } \\
\text { 2) Increase the credit support of the new type of main } \\
\text { production. } \\
\text { 3) Take small credit as major part to promote financial } \\
\text { products innovation. } \\
\text { 4) Promote the innovation of collateral replacement } \\
\text { mechanism. }\end{array}$ \\
\hline
\end{tabular}

\section{Conclusion}

At present, the new agricultural social service organization in China has formed two categories of service organization that takes a basic public service as the leading, and management service as the supplement. They form organic combination and mutually supplement organizational system around each link of the agricultural production, whose development has become one of the hot topics in academic circles at present. Based on this, this article primarily discusses the current development of new agricultural social service organizations in China, and based on its current development situation, solves the existing problems, and puts forward 6 suggestions to promote the development of the new agricultural social service organizations in our country, which provides reference and basis for its development to a certain extent and has the important theoretical significance and practical value.

\section{Reference}

[1] Choi, D. W., An, W. H., \& Lin, Q. L. (2015). A Study on the Development of Evaluation Indicator for Brand Self-diagnosis of Agricultural Management Organizations. Journal of Agricultural Extension \& Community Development, 22(4), 385-393.

[2] Cohen, L. E. (2016). Jobs as Gordian Knots: A New Perspective Linking Individuals, Tasks, Organizations, and Institutions. In The structuring of work in organizations (pp. 25-59). Emerald Group Publishing Limited.

[3] Deng, A. M., Zhong, H. F., Li, H. L., \& Wang, J. (2013). Review of Researches on Logistics Industry Clusters Sustainable Development. In International Asia Conference on Industrial Engineering and Management Innovation (IEMI2012) Proceedings (pp. 1227-1235). Springer Berlin Heidelberg.

[4] Farrington, J., \& Lewis, D. J. (Eds.). (2014). Non-governmental organizations and the state in Asia: Rethinking roles in sustainable agricultural development. Routledge.

[5] Holzworth, D. P., Huth, N. I., Zurcher, E. J., Herrmann, N. I., McLean, G., Chenu, K., ... \& Brown, H. (2014). APSIM-evolution towards a new generation of agricultural systems simulation. Environmental Modelling \& Software, 62, 327-350.

[6] Ivanova, M. N. (2012). Economic risks of agricultural organizations' activity in the Vologda Oblast in the context of Russia's membership in WTO. AND SOCIAL CHANGES, 68.

[7] Kerr, R. B. (2012). Lessons from the old Green Revolution for the new: Social, environmental and nutritional issues for agricultural change in Africa. Progress in Development Studies, 12(2-3), 213-229.

[8] Niewolny, K., Grossman, J., Byker Shanks, C., Helms, J., Clark, S., Cotton, J., \& Jacobson, K. (2012). Sustainable agriculture education and civic engagement: The significance of community-university partnerships in the new agricultural paradigm. Journal of Agriculture, Food Systems, and Community Development, 2(3), 27-42. 
[9] Peterman, A., Behrman, J. A., \& Quisumbing, A. R. (2014). A review of empirical evidence on gender differences in nonland agricultural inputs, technology, and services in developing countries. In Gender in Agriculture (pp. 145-186). Springer Netherlands.

[10] Rizzo, M., Pilato, M., Popescu, G., Istudor, N., \& Boboc, D. (2013). The traceability of agricultural products in Direct Selling Organizations (DSO). In Proceedings, 1st International Conference" Competitiveness of agro-food and environmental economy (CAFEE 12)", Bucharest, 8-9 November 2012 (pp. 346-356). Academy of Economic Studies.

[11] Stamoulis, K., \& Hemrich, G. (2016). Hunger, food insecurity and malnutrition: new challenges for international organizations. Rivista di Economia Agraria, 71(1), 13-18.

[12] Ugwuoke, C. U., \& Onah, B. I. (2015). Skills Required by Agricultural Education Students of Colleges of Education for Employment in Computerized Office of Agribusiness Organizations. Journal of Education and Practice, 6(29), 84-91.

[13] ZHI, Y. E., \& ZHUANG, T. H. (2015). The Operation Patterns and Effect Evaluation of Agricultural Professional Service Organizations: A Case Study of Chongzhou Agricultural Service Supermarkets. Journal of Sichuan Agricultural University, 2, 017. 